\title{
Practices of Cross-Cultural Etiquette and Communication in Global Business - A Conceptual Analysis on Managing Corporate Expansion: A Review Study
}

Touhidul Islam*

Faculty of Business Studies, University of Dhaka, Dhaka, Bangladesh

\begin{abstract}
Today's Business area has no boundary. It conducts its activity all over the world with its own trends but the marketers must consider the external business factors to run the business successfully all over the world. Cross-Cultural Etiquette is one of the most important factors that must be considered to grow the business globally. The aim of this article review is to analyze the Cross-Cultural Etiquette in respect of strategic Business Manager. The author of this article tries to give an overview about Cross-Cultural Etiquette and its necessity for fruitful business communication for the strategic business manager. In twenty first century this article is related to the current business Etiquette and communication and maintains the accuracy, currency and stability so it is highly credible and relevant to the current business environment.
\end{abstract}

Keywords: Global business; Cultural etiquette; Managing corporate; Business

\section{Introduction}

This is critically review of article of "Cross-Cultural Etiquette and Communication in Global Business: Toward a Strategic Framework for Managing Corporate Expansion" published by Canadian Center of Science and Education in the International Journal of Business and Management. This article review consist of summarize the article and analyses the effectiveness of article's structure. It will also investigate the article's accuracy, currency and relevancy. This review will also inform that how this article relevant to the current world and how it is related to its objectivity and stability. Finally this review will provide conclusion with recommendations and suggestions that will beneficial to the relevant groups like future researchers, business organization and government for the whole world.

\section{Article summary}

The motive of this article is to provide a clear idea about the management role to sustain in the global market by considering the International business Etiquette and cross cultural differences. This study is an exploratory type article that provides an analysis about the effectiveness of Cross-cultural communication and global workforce diversity [1]. It provides the ways to maintain the crosscultural communication that is helpful for international management assignment. This article shows the skills required for the Global managers for increasing the scope and global trends and investment. The author of this article has provided a vast analysis with the references of current literature work on managing for worldwide competitive advantage through many elements that makes the international business managers to communicate and negotiate with different countries for gaining substantial prominence in worldwide Business. This article has provided some effective rules of Etiquette in cross-cultural business like cross-cultural exchange, cross-cultural negotiation, and multinational assignment, cultural and regulatory variations. This study also provided the requirements of International business etiquette for gaining current and future business trends. It has been shown that there is a positive relationship between cross-cultural communication and effective international management [2].

\section{Article structure}

This article has started with an Abstract that provides the brief overview of the main theme of this study. After the abstraction section the body of this article has been started from Introduction. As it is exploratory and literature review based article so it does not properly mention the rational, objectives and scope of the article but the author has provided Six points/Headings for discussing and analyzing the subject matter for the constructive evaluation and analysis of Global etiquette and cross-cultural communication [3]. Through these six headings the author has tried to provide detailed information and exploration about the cross-cultural etiquette and communication and the role of Business managers to maintain the effective international relationship to compete and to sustain in the Global market. There are no graphs and tables in this article for providing numerical and statistical data [4,5]. The Methodology section of this article is not present but as this study is an exploratory research so this Author has been used the secondary information and by exploration of this information the author has provided the importance of cross-cultural Etiquette in the changing business world. By giving lot of examples and quotations, the author has provided the output and implications of this study. In the last section the Article has provided the conclusion, suggestion, recommendation for business managers to achieve desired return on investment in International competitive business with the difference of cultural and business etiquette [6-8]. References and links and literature citation have been clearly used in the text of article. This article is PDF as well as HTML format which include many links to author and references of books, journal, subjects, citation which are authentic and helpful to access and evaluate information and the main theme of this article easily to the readers.

\section{Article critique authority}

This article published by Canadian Center of Science and Education

*Corresponding author: Touhidul Islam, MPhil, Faculty of Business Studies, University of Dhaka, Dhaka, Bangladesh, Tel: +88029661900; E-mail: touhidpust@gmail.com

Received June 01, 2017; Accepted July 31, 2017; Published August 10, 2017

Citation: Islam T (2017) Practices of Cross-Cultural Etiquette and Communication in Global Business - A Conceptual Analysis on Managing Corporate Expansion: A Review Study. J Bus Fin Aff 6: 280. doi: 10.4172/2167-0234.1000280

Copyright: (c) 2017 Islam T. This is an open-access article distributed under the terms of the Creative Commons Attribution License, which permits unrestricted use, distribution, and reproduction in any medium, provided the original author and source are credited. 
which is an unbiased organization and it is published in 'International Journal of Business and Management' [9-11]. It is print as well as online version article. It is found on the Google scholar, researchgate. net, Linkedin.com, academia and the website of International Journal of Business and Management'. The credibility of Author was established in a number of ways like the author Dr. Ephraim OKoro [1] is a Professor of Business Communication/Marketing at Howard University, School of Business, Washington DC. He is also an Academic Advisor, Educational Consultant and Administrator/ Management in Higher Education. He obtains the PhD, MBA, MPA degree from Howard University. He has about 57 research papers and Articles (Sited by Google Scholar). So, it is clear that the Author is a renowned and skilled researcher in academic and professional sector.

Accuracy: As this article has been published in 16 August, 2012, so obviously it is current research project. The article is supported by comprehensive and vast references ranging from 1974-2011 and these sources are cited in the text and Article review section of this Article that flourish the quality of research. International Journal of Business and Management is peer review, indexed and impact factor International journal so its strict editorial and reviewing process contributed to the Accuracy of this Article.

Currency: The Article was receiver in March 22, 2012, accepted in June 8, 2012 and published in August 16, 2012. The Article described the information and concepts that were current and this article contain update references and links ranging from 1974-2011 which is very recent. This study contains the fair data sources which are using in current research process so this Article is current.

Relevance: As the article topic is related to the current business Etiquette and communication so it is highly credible and relevant to the current business environment and it is academic as well as professional business context. The author has developed this article to provide a constructive evaluation and analysis of Global etiquette and crosscultural communication which are so relevant and helpful for current global managers, future researchers and academic scholars $[12,13]$.

\section{Objectivity}

This article has been developed according to its objectivity and the information of this article is well supported with current research base and with all evidences, links and references $[14,15]$. This article is free of bias because it has been published in International Journal of Business and Management (IJBM) which is an international, renowned and indexed; double-blind peer-reviewed, open-access journal and this article is published by Canadian Center of Science and Education. This article is exploratory research so it has explored its key terms to fulfill its objectives. The purpose of this study is to know and analysis the global cross-cultural communication, cultural awareness, business etiquette and sensitivity. The author has tried to discuss the issues (cross-cultural etiquette, global communication and management strategic framework) with numbers of ways like providing various related examples and current related reference to support its research decision.

\section{Stability}

This article was published in International Journal of Business and Management which is an international, double-blind peer-reviewed, open-access journal. This article is published by the Canadian Center of Science and Education. This Journal utilizes the LOCKSS system and it has about 15 index/lists. So this article is stable as a resource for the academician, researcher and Global business Managers [16].

\section{Recent Advance Related to the Topic}

As this article has been published in 2012 and off course it is very recent and its subject matter is mostly relevant to the present scenario of Global business because it has discussed the most vital issue in business that it Cross-cultural and communication in global business [17]. This article also suggests lot of strategies for the business managers to compete in the global market and to gain sustainable advantage in competitive global business. The author has critically analyzed this topic with huge related literature reviews that is ranging from (19722011) so by considering this article's subject matter the present global business managers can develop their strategies to understand, maintain and aware the it Cross-cultural and communication in global business. Depending on information of this article lot of research paper has been developed and this topic helps to the development and advances in the present global Business etiquette and its environment because this topic covers the rules of Etiquette, cross-cultural effectiveness, strategies for global managers etc [18]. Today Great Britain, Germany, Japan, China, USA and other European countries are specially practicing this issue (Cross-cultural etiquette and global communication) and they are overcoming the hindrances of Cross-cultural etiquette and developing their business in Global market. In 2013 Okoro has shown his papers that how different countries increase their sensitivity and respect for one another's cultural differences in order to benefit from the growth of international business in the twenty-first century [1]. Recent studies said that "Class status in important to Germans, and even though all people have equal rights under the law, in reality inequalities exist" [2]. Recent study shows and gives emphasis on intercultural communication and etiquette in international businesses that is important of understanding the cultures and values of their counterparts as well as develops intercultural communication sensitivity for gaining desired return on investment and success in international market [4].

\section{Conclusion}

Review of this article is both summarized and critically reviewed. The author has provided some guidelines and ways to get success in the competitive business with cross-cultural differences. This article has been analyzed, critiqued the contents, strength and limitations. It is based on survey of current and past related literatures that gives the overview of scope of global trends and investment for next several decades. It has provided the strategies like negotiating, managing, communicating across cultural differences in the International business. It has provided necessary information to understand appropriate business etiquette, customs, and values needed to conduct business among nations of the world that is helpful for future research and for the recent business leaders.

\section{References}

1. Okoro E (2013) International organizations and operations: An analysis of cross-cultural communication effectiveness and management orientation. Global Journal of Management and Business Research 12: 47-53.

2. Chaney LH, Martin JS (2011) Intercultural business communication. ( $4^{\text {th }}$ edn.) Upper Saddle River, Pearson Prentice Hall, NJ.

3. Ke G (2011) Cultural Difference Effects on Business: Holding up Sino-US Business Negotiation as a model/les effets de la difference culturelle sur les affaires: En prenant la négociation sino-américaine comme un modèle. CrossCultural Communication 7: 101

4. Washington MC, Okoro EA, Thomas O (2012) Intercultural communication in global business: An analysis of benefits and challenges. The International Business \& Economics Research Journal 11: 217.

5. Okoro EA, Washington MC (2012) International Business Environment: An Analysis of Intercultural Communication and Etiquette. Research Yearbook. 
Citation: Islam T (2017) Practices of Cross-Cultural Etiquette and Communication in Global Business - A Conceptual Analysis on Managing Corporate Expansion: A Review Study. J Bus Fin Aff 6: 280. doi: 10.4172/2167-0234.1000280

Page 3 of 3

6. Jiang Y (2013) Business Negotiation Culture in China-A Game Theoretic Approach. International Business Research 6: 109.

7. Bülow AM, Kumar R (2011) Culture and negotiation. International Negotiation 16: 349-359.

8. Sarkar AN (2010) Navigating the rough seas of global business negotiation: Reflection on cross-cultural issues and some corporate experiences. International Journal of Business Insights \& Transformation 3: 47-61.

9. Beckers AM, Bsat MZ (2014) An analysis of intercultural business communication. Journal of Business and Behavior Sciences 26: 143.

10. Okoro E (2013) An Integrative Framework for International and Intercultural Communication Contexts: Conflicts, Ferment and Theoretical Analysis. Journal of Business Theory and Practice 1: 37.

11. Liu M, Wilson SR (2011) The effects of interaction goals on negotiation tactics and outcomes: A dyad-level analysis across two cultures. Communication Research 38: 248-277.
12. Kumar R, Patriotta G (2011) Culture and international alliance negotiations: A sense making perspective. International Negotiation 16: 511-533.

13. Seligman SD (2008) Chinese business etiquette. A Guide to Protocol, Manners and Culture in the People's Republic of China. New York.

14. Martin JS, Chaney L H (2012) Global Business Etiquette: A Guide to International Communication and Customs. ABC-CLIO.

15. De Mente, Lafayette B (1989) Chinese etiquette and ethics in business.

16. Rowland D (1993) Japanese business etiquette: A practical guide to success with the Japanese. Warner books.

17. Wilson D, Donaldson L (1996) Russian etiquette \& ethics in business. McGraw Hill Professional.

18. Sabath AM (2005) International Business Etiquette: What You Need to Know to Conduct Business Abroad with Charm and Savvy. iUniverse, Europe. 